\title{
A NEW METHOD OF JOB EVALUATION
}

\author{
Wiktor Adamus \\ Jagiellonian University, Poland \\ wiktor.adamus@uj.edu.pl
}

Key words: job evaluation, new method, Analytic Hierarchy Process

\section{Introduction}

Job evaluation is a crucial point in human resources management. The aim of human resources management is linking employees with their work results which should met in order for an organization to fulfill its tasks. Thus, job evaluation occurs as an irreplaceable factor that enables management through learning the necessary values. Enhancing the efficiency of a company depends on various endogenous and exogenous factors. Job evaluation may be the aspect that tips the scales in your competition's favor. The evaluation itself is an analysis and assessment of requirements aiming at valuation of job quality.

The results of job evaluation are used in human resources management, particularly in creating remuneration systems, i.e. decision making process concerning the differences between payments for different jobs. Many job evaluation methods have been developed in the previous century. Yet none of them defines directly the relative value of given job posts within an organization. The aim of this article is to work out a new method measuring quality features of jobs in a simple, transparent, universal and timeless way.

The method itself is a development of the concepts and remarks of authors specializing in the field of job evaluation, as well as of practical experiences and implementation of modern knowledge coming from cognitive psychology, behavioral patterns in organizations and applied mathematics, including multicriteria decision support.

The additional cause for reexamining the issues was the fact that the most popular job evaluation methods (analytical point ranking) did not change much since the beginning of the 20th century, when they were established. 


\section{The Essence of Job Evaluation}

Job evaluation is a technique used to measure the quality features of work. M. Armstrong describes job evaluation as a "systematic process of determining the relative value of different job posts within an organization". Many methods that enable its measurement process have been established (see Table 1). The main issue is that the measured analytic criteria within the synthetic criteria were assigned to arbitral point values, for which there was often no logical explanation offered.

Table 1. Characteristics of chosen job evaluation methods

\begin{tabular}{|c|c|c|c|}
\hline Method Name & Characteristics & Merits & Flaws \\
\hline Ranking job posts & $\begin{array}{l}\text { A summary method based on ranking } \\
\text { job posts from the hardest to the easiest } \\
\text { ones }\end{array}$ & $\begin{array}{l}\text { - Easy to use } \\
\text { - Easily understood by the } \\
\text { employees }\end{array}$ & $\begin{array}{l}\text { - No definition of a model } \\
\text { - The least accurate } \\
\text { - Does not measure the difficulty } \\
\text { of a job } \\
\text { - Hard to explain }\end{array}$ \\
\hline Classifying job posts & $\begin{array}{l}\text { A summary method based on grouping } \\
\text { job posts into homogenous classes } \\
\text { (categories); the jobs are then compared } \\
\text { to a model }\end{array}$ & $\begin{array}{l}\text { - Easy to use } \\
\text { - Easily understood by the } \\
\text { employees }\end{array}$ & $\begin{array}{l}\text { - Subjective in character } \\
\text { - Hard in creating good job } \\
\text { descriptions } \\
\text { - Does not measure the difficulty } \\
\text { of a job }\end{array}$ \\
\hline Comparing factors & $\begin{array}{l}\text { An analytical method based on } \\
\text { determining the right hierarchy of job } \\
\text { posts regardless of level of job } \\
\text { difficulty }\end{array}$ & $\begin{array}{l}\text { - Universal - it can be used in } \\
\text { different organizations }\end{array}$ & $\begin{array}{l}\text { - Difficult in appropriate selection } \\
\text { of key job posts } \\
\text { - Subjective in character }\end{array}$ \\
\hline $\begin{array}{l}\text { Analytical point } \\
\text { ranking }\end{array}$ & $\begin{array}{l}\text { Methods based on determining the level } \\
\text { of job difficulty on the basis of analysis } \\
\text { of previously described criteria and } \\
\text { comparing them to the scale; a given } \\
\text { number of points is attributed to each } \\
\text { criterion }\end{array}$ & $\begin{array}{l}\text { - Easy in evaluating and } \\
\text { describing the differences } \\
\text { between posts } \\
\text { - Takes into account more } \\
\text { factors influencing the difficulty } \\
\text { level of a job post } \\
\text { - Gives the evaluator defined } \\
\text { evaluation criteria } \\
\text { - Guarantees a flexible relation } \\
\text { between work and remuneration }\end{array}$ & $\begin{array}{l}\text { - Its creation, implementation and } \\
\text { application is complicated } \\
\text { - It requires a great deal of } \\
\text { knowledge on occupations, posts, } \\
\text { tasks etc. from the people creating } \\
\text { the remuneration systems } \\
\text { - Surface objectivity - giving } \\
\text { points to criteria is based on } \\
\text { subjective evaluation } \\
\text { - Difficulty in explaining the } \\
\text { difference between various levels } \\
\text { of established criteria }\end{array}$ \\
\hline $\begin{array}{l}\text { Bedaux's Method, } \\
\text { Ch. Bedaux (1916) }\end{array}$ & $\begin{array}{l}\text { An analytical method based on point } \\
\text { evaluation of requirements for various } \\
\text { jobs carried out by employees }\end{array}$ & $\begin{array}{l}\text { - Takes into account more } \\
\text { factors influencing the difficulty } \\
\text { level of a job post }\end{array}$ & $\begin{array}{l}\text { - Laborious } \\
\text { - It requires a great deal of } \\
\text { knowledge on occupations, posts, } \\
\text { tasks etc. from the people creating } \\
\text { the remuneration systems }\end{array}$ \\
\hline $\begin{array}{l}\text { Hay Guide Chart and } \\
\text { Profile Method (E.N. } \\
\text { Hay) (www. } \\
\text { Haygroup.com) }\end{array}$ & $\begin{array}{l}\text { An analytical point ranking method } \\
\text { based on three synthetic criteria: know- } \\
\text { how, problem solving and } \\
\text { accountability, which were extended by } \\
\text { analytical and fragmentary criteria - all } \\
\text { to enable examining job features in } \\
\text { terms of their difficulty }\end{array}$ & $\begin{array}{l}\text { - Mostly used in case of } \\
\text { managerial posts evaluation } \\
\text { - Constantly developed and } \\
\text { modified by consultants of Hay } \\
\text { Group, based on experience } \\
\text { from over } 40 \text { countries } \\
\text { worldwide }\end{array}$ & $\begin{array}{l}\text { - Aimed at evaluating non- } \\
\text { production jobs } \\
\text { - It is difficult in comprehension } \\
\text { for the employees }\end{array}$ \\
\hline
\end{tabular}




\begin{tabular}{|l|l|l|l|}
\hline $\begin{array}{l}\text { Scheme of Geneva, } \\
\text { International Labor } \\
\text { Organization (ILO) } \\
\text { (1950) }\end{array}$ & $\begin{array}{l}\text { A method unifying different, practical } \\
\text { criteria of job evaluation dividing them } \\
\text { into synthetic and analytical ones }\end{array}$ & $\begin{array}{l}\text { - The basis for many job } \\
\text { evaluation methods, especially } \\
\text { in industrial companies }\end{array}$ & $\begin{array}{l}\text { - Used to evaluate difficulty for } \\
\text { blue-collar posts }\end{array}$ \\
\hline $\begin{array}{l}\text { Jniversal Method of } \\
\text { (UMEWAaluan }\end{array}$ & $\begin{array}{l}\text { Point ranking method referring directly } \\
\text { to the Scheme of Geneva; it uses for } \\
\text { synthetic criteria }\end{array}$ & $\begin{array}{l}\text { - Universal - used for } \\
\text { evaluation of managerial and } \\
\text { executive posts in all branches } \\
\text { of economy }\end{array}$ & $\begin{array}{l}\text { - Laborious } \\
\text { in case of lack of independence } \\
\text { erroneous evaluation by inflating } \\
\text { value of work or faking the whole } \\
\text { process }\end{array}$ \\
\hline $\begin{array}{l}\text { National Joint } \\
\text { Council (NJC) (1997) }\end{array}$ & $\begin{array}{l}\text { Job evaluation for blue-collar workers } \\
\text { and administrative staff based on 13 } \\
\text { synthetic criteria }\end{array}$ & $\begin{array}{l}\text { - Only one evaluation criterion } \\
\text { is used to assess the know-how } \\
\text { really needed to perform tasks } \\
\text { on a given post }\end{array}$ & $\begin{array}{l}\text { - No analytical criteria } \\
\text { - Comparable range of interaction } \\
\text { of all 13 criteria }\end{array}$ \\
\hline $\begin{array}{l}\text { Questionnaire Job } \\
\text { Evaluation (AWP, } \\
\text { AWP-N, AWP-2BIS) }\end{array}$ & $\begin{array}{l}\text { Point ranking method based on the } \\
\text { Scheme of Geneva referring directly to } \\
\text { the UMEWAP method }\end{array}$ & $\begin{array}{l}\text { - Easy to use } \\
\text { - Greater differentiation in point } \\
\text { ranking of posts }\end{array}$ & $\begin{array}{l}\text { - Laborious } \\
\text { - Encourages omitting job } \\
\text { descriptions }\end{array}$ \\
\hline $\begin{array}{l}\text { Market-based job } \\
\text { evaluation }\end{array}$ & $\begin{array}{l}\text { A method based on evaluation of pay } \\
\text { rates in comparison with the market pay } \\
\text { rates for similar job posts }\end{array}$ & $\begin{array}{l}\text { - The job is paid as much, as the } \\
\text { market is willing to pay for it }\end{array}$ & $\begin{array}{l}\text { - Does not take into account that } \\
\text { values of posts in one } \\
\text { organization may differ from } \\
\text { values in other organizations } \\
\text { - Difficulty in acquiring } \\
\text { information about pay rates on the } \\
\text { market }\end{array}$ \\
\hline
\end{tabular}

Source: Personal study

Job evaluation methods are covered in about every book on human resources management, e.g. [Armstrong 2005, Banfield, Kay 2008, Król, Ludwiczyński 2006, Rostowski 2003]. Details on individual job evaluation methods may be found in works of [Armstrong et al. 2008, Borkowska 2006, Juchnowicz, Sienkiewicz 2006, Martyniak 1998, Poels 2000, Wartościowanie stanowisk pracy... 2008]

People, even these having the appropriate expertise, are known to be poor at estimating and comparing objects of similar value. Scales with several extremes and distant levels, sometimes even differentiated by description or examples are reasonable for qualitative, as well as criteria primarily measured quantitatively. The limitations in human estimation and comparison abilities in terms of multiple criteria may lead to inconsistencies in evaluation or oversimplification of rules, which will omit the clear aspects of each model of job evaluation.

For instance, in research conducted by specialists, who evaluated job applicants, it occurred their evaluations were similar when they used a scale with small number of verbal marks and more differentiated when they used a qualitative scale from 1 to 10 [Moshkovich et al. 2005].

Number of compared elements " $n$ " should be in the (5-9) bracket. The range was determined by the so-called Magical Number 7, i.e. 7+/-2 [G. Miller 1956]. With a larger number of compared criteria, there is a higher risk of erroneous opinions and conclusions. This means that human mind cannot comprehend a larger number of variables and compare them in a correct manner. These facts were repeatedly confirmed by psychological research [Blumenthal 1977, Miller 1956, Tversky 1971, Larichev 1984, Larichev, Moshkovich, Rebrik 1998] 
Problems with using accurate quantitative estimates from the decisionmakers may be overcome by using information preferential to a given decisionmaker (e.g. "presumably", "definitely" etc.)

Verbal descriptions arranged in terms of different levels, and not numerical values not only make the decision-makers more comfortable with their assessments, but also should lead to achieving more stable, clear-cut results. People prefer to use verbal communication than quantitative statements. Words are received by interlocutors as more flexible and less precise; therefore they fit the description of vague opinions. I. Erev i B. Cohen found that making people use quantitative phrases, statements on unclear situations, when it is only possible to differentiate between a few levels of probability, may lead to confusing estimates [Erev, Cohen 1990].

The research have shown that quantitative assessment and comparison of different objects is more difficult for people than making the same mental effort with using qualitative tools for expressing one's preferences [Moshkovich et al. 2005]. Therefore in our job evaluation method we will use scales based on verbal descriptions, which after their quantification (scaling) will provide a quantitative aspect for criteria in job evaluation models. The number of synthetic, as well as analytical and fragmentary criteria will not in any circumstances exceed 7 , as in the proposed method.

\section{Steps (phases) in the measurement method of qualitative features of jobs}

In job evaluation, the following phases are proposed:

1. Introducing the problem - developing a new method of measuring quality features of jobs (job evaluation) in a simple, transparent, universal and timeless way,

2. Identifying the main aim - a relative assessment of job posts in an organization,

3. Knowing the exterior and interior factors determining the value of job posts,

4. Establishing a multi-level structure of a problem in the form of a hierarchical tree, the main, the main criteria (synthetic), sub-criteria (analytical criteria) and degrees of intensity of each analytical criterion (Fig. 1), 
Fig. 1. Hierarchical structure of job evaluation

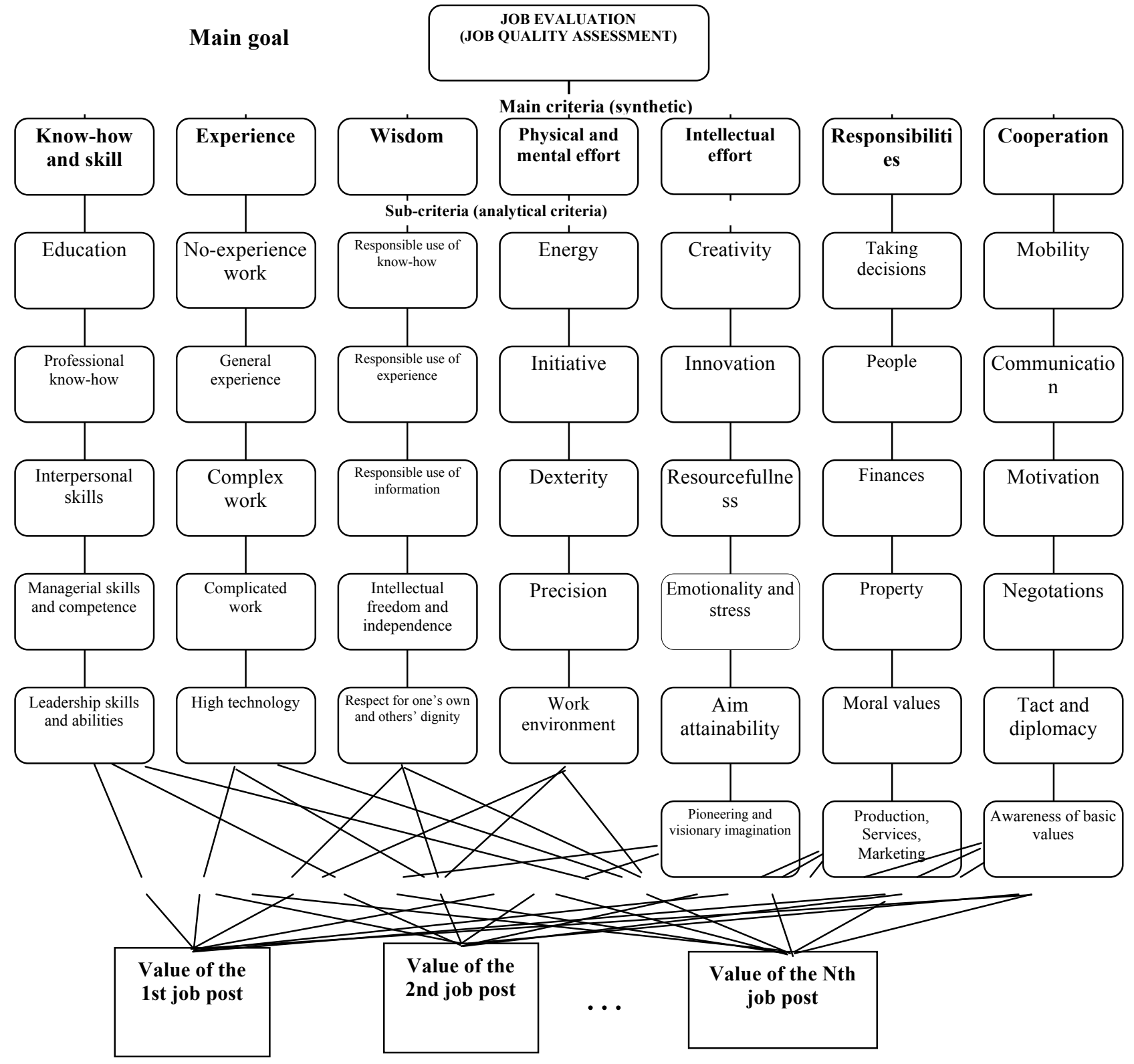

Source: Personal study 
5. Determining the dominance (preferences) of synthetic criteria by comparing in pairs (each one with each one) their importance (verbal opinions) with reference to job value based on the fundamental preference scale of T. Saaty (Table 2),

Table 2. The 9-point scale for pairwise comparisons

\begin{tabular}{|c|c|c|}
\hline $\begin{array}{l}\text { Importance } \\
\text { Preference } \\
\text { Likehood }\end{array}$ & Definition & Explanation \\
\hline 1 & $\begin{array}{l}\text { Equal importance / } \\
\text { preference / likehood }\end{array}$ & $\begin{array}{l}\text { Two elements contribute equally to the } \\
\text { goal / parent element }\end{array}$ \\
\hline 3 & Weak dominance & $\begin{array}{l}\text { Experience or judgment slightly favors } \\
\text { one element over another }\end{array}$ \\
\hline 5 & Strong dominance & $\begin{array}{l}\text { Experience or judgment strongly favors } \\
\text { one element over another }\end{array}$ \\
\hline 7 & $\begin{array}{l}\text { Demonstrated (very } \\
\text { strong) dominance }\end{array}$ & $\begin{array}{l}\text { Experience or judgment strongly very } \\
\text { strongly favors one element over another } \\
\text { (an element's dominance is demonstrated } \\
\text { in practice) }\end{array}$ \\
\hline 9 & Absolute dominance & $\begin{array}{l}\text { The evidence favoring an element over } \\
\text { another is affirmed to the highest possible } \\
\text { order }\end{array}$ \\
\hline $2,4,6,8$ & Intermediate values & $\begin{array}{l}\text { Further subdivision or compromise is } \\
\text { needed }\end{array}$ \\
\hline $\begin{array}{l}\text { Reciprocals of } \\
\text { the above }\end{array}$ & $\begin{array}{l}\text { If activity } i \text { has one of } \\
\text { the above nonzero } \\
\text { numbers assigned to it } \\
\text { when compared with } \\
\text { activity } j \text {, then } j \text { has } \\
\text { reciprocal value when } \\
\text { compared with } i \text {. }\end{array}$ & i.e. If $x$ is 5 times $y$, then $y=x / 5$ \\
\hline Rationals & $\begin{array}{l}\text { Rations arising from } \\
\text { the scale }\end{array}$ & $\begin{array}{l}\text { If consistency were to be forced by } \\
\text { obtaining n numerical values to span the } \\
\text { matrix }\end{array}$ \\
\hline
\end{tabular}

Source: Saaty, 2001

The person comparing the criteria is to answer a list of questions, such as: which of the synthetic criteria for the evaluator (specialist) is more important in terms of job value (quality), and which of the analytical criteria are important when it comes to a given synthetic criterion, as well as how much more important are they on a scale from total balance to total advantage. The task of the evaluator is to mark in pairs, by using the table, the preference for domination (advantage) criteria of one criterion over another on a verbal scale choosing from weak, strong, extremely strong and total advantage. 
If one of the criteria has an advantage over another one in terms of comparison (a case of equivalence of both criteria in evaluation of job quality), the evaluators (specialists) mark equal domination of criteria (no advantage), describing this fact in the table as "balance".

The comparisons are done by experts, researchers - specialists in the field of human resources management, practitioners - human resources managers, company directors,

6. Determining in the hierarchy preferences of analytical criteria through comparison in pairs of their importance juxtaposed to the values of each synthetic criterion, using the fundamental preference scale of T. Saaty,

7. Determining the verbal level of intensity of each analytical criterion in order to establish multi-level partial criteria of job evaluation,

8. Quantification of verbal opinions on importance of comparison of synthetic criteria based on the fundamental preference scale of T. Saaty. Quantities should be relatively stable,

9. Quantification of verbal opinions on importance of comparison of analytical criteria. These quantities should be also relatively stable,

10. Quantification of adjectival, verbal degrees of intensity for analytical criteria,

11. Determining "local" priorities (weights) in the $[>0,<1]$ bracket for each synthetic $P_{s_{i}}$ and analytical $P_{a l_{i j}}$ criterion through normalization of own vectors from the comparison matrix. The determined weights for individual criteria prove their importance in job evaluation,

12. Determining numerical priorities $N_{a_{i j k}}$ for each fragmentary criterion (intensity degree of analytical criteria). These quantities vary, depending on individual organizations, job posts, time and other internal and external factors,

13. Determining the conformity rate CR (verbal consistency of comparison in pairs) of synthetic, analytical and fragmentary criteria of degrees of intensity. The acceptable limit of error for opinions should not exceed $10 \%$. It is not acceptable for it to be higher. Similarly, $100 \%$ consistency in comparisons $(\mathrm{CR}=0)$ should not be tolerated. If one is sticking obstinately to his/her convictions, it means there is no possibility to change his/her opinion. Yet by acquiring knowledge and new experiences, it is common to change one's views and see issues in a new, sometimes better way. In this way opinions are bound to change,

14. Determining the global priority for each analytical criterion on the basis of the following formula: 


$$
P_{g_{i j}}=P_{s_{i}} \times P_{a l_{i j}}
$$

where: $\quad P_{g_{i j}}-$ global weight (priority) of j-analytical criterion in comparison with i-synthetic criterion, $P_{s_{i}}$ - weight (priority) i-synthetic criterion, $P_{a l_{i j}}-$ local weight (priority) of j-analytical criterion in comparison with i-synthetic criterion,

The size of global priority results in a percentage ,share” of a given subcriterion in the total evaluation of a job post,

15. A description and analysis of jobs including quality (difficulty) evaluation criteria expressed by a verbal, adjectival degree of intensity of each analytical criterion. The task of the person describing a post is a verbal objective assessment in a three or five-degree adjectival scale of analytical criteria intensity attributed to a given job post,

16. Determining the number of points for each job by means of the following formula:

$$
W_{s_{i}}=\sum_{j=1}^{n}\left(P_{g_{i j}} \times N_{a_{i j k}} \times 10000\right)
$$

where:

$W_{s_{i}}$ - point value of i-position,

$P_{g_{i j}}-$ global weight (priority) of j-analytical criterion in comparison with i-synthetic criterion,

$N_{a_{i j k}}$ - weight (priority) k-intensity in j-analytical

criterion and i-synthetic criterion,

10000 - conversion rate changing fractions into integral numbers for better response of an evaluated job post by the employees of an organization,

17. Estimating financial value in the domestic currency of a given value in a given company and to a point in job evaluation $\mathrm{P}_{\mathrm{i}}$. These quantities are variable,

18. Establishing fiscal value of each job posts on the basis of the following formula:

$$
V_{f s_{i}}=W_{s_{i}} \times P_{i}
$$

where: $V_{f s_{i}}-$ financial value of i-job, 


$$
\begin{aligned}
& W_{s_{i}}-\text { point value of } \mathrm{i} \text {-job, } \\
& P_{i}-\text { financial value of a single point in job evaluation }
\end{aligned}
$$

19. Determining rating matrixes (tables) for all job posts in an organization,

20. Establishing a fundamental pay scale in an organization.

\section{Hierarchy of job evaluation issues}

A decision-maker, who is naturally interested in the results, may also want to control the whole process by choosing the experts or influencing the rules behind decisions. Such issues may be solved by multi-criteria methods of decision support. In this case to solve a given problem the multi-criteria method of decision support - Analytic Hierarchy Process (AHP) [T. Saaty, 2006] was introduced.

The following criteria are usually listed for job evaluation methods:

- Skills (know-how, experience, job complexity),

- Responsibility (for people, for moral values, for tangible property),

- Problem solving (knowledge and intellectual processes vital for solving problems effectively),

- Work conditions,

- Decision-making and powers on a given post,

- Communication and contrariness,

- Competence of employees.

In this method, the system of values for job posts was based on 7 main (synthetic) criteria: know-how and abilities, experience, wisdom, physical and mental effort, intellectual effort, responsibility, cooperation (see Fig.1).

\section{Quantification of verbal opinions}

Each synthetic criterion was assigned with a few sub-criteria - analytical criteria (see Fig. 1). Each analytical criterion was given in turn adjectival, verbal degrees of intensity.

Every person takes dozens of decisions each day considering different criteria in the choice of alternatives fulfilling a set of desirable effects. The decision is a choice of one of the alternatives which according to the evaluator fulfills in an optimal way the aims of the decision. Making choices and taking decisions is one of the basic human activities. The importance, dominance, preference of different criteria in realization of the main aim (taken decision) is described on the basis of comparison in pairs of each and every criterion 
[Adamus, Gręda 2005]. These comparisons are done on the basis of knowledge, experience, competence, wisdom and responsibility, as well as emotions.

By comparing the importance of each synthetic criterion in the fundamental comparison scale of T. Saaty (see Table 2) to job quality, from the matrix of comparisons a point evaluation of criteria equaling 1 was achieved.

Each synthetic criterion was related to analytical criteria. Their importance was compared on the T. Saaty's scale. Each of the analytical criteria (subcriteria) was assigned a weight (priority), which total sum for each criterion is one. These quantities were established as relatively constant. Next to each sub-criterion (analytical criterion) in the quality evaluation a degree of intensity was assigned.

Intensities - point weights of fragmentary criteria assigned to the appropriate analytical criteria may vary, as they depend on e.g.:

- the size of a company,

- the type of production or service,

- the number of posts for evaluation,

- the complexity of jobs,

- the time window in which the posts are evaluated,

- other evaluation factors.

Given the above-mentioned determinants, this method established initially two types of adjectival scales: $\mathrm{A}-\mathrm{a}$ three-point one (see Table 3 ) and $\mathrm{B}-\mathrm{a}$ fivepoint one (see Table 4).

By paired comparison of verbal evaluations in the fundamental comparison scale of T. Saaty, both verbal scales were assigned numerical weights (priorities). In both adjectival scales there were several degrees of intensity for analytical criteria (see Tables 3 and 4).

Weights (numerical priorities) for different verbal evaluations were presented respectively in Tables 3 and 4 . We suggest using 5-degree scales in companies with greater diversity of job posts. 3-point scales are preferable for companies which have relatively low job and task diversity. Furthermore, both 3-point and 5-point scales were assigned with diversified degrees of intensity. Analytical criteria of lesser complexity are in need of lower numerical scale range, and conversely criteria of greater complexity should have high range of numerical scales. For example, synthetic criteria for know-how and skills are based on adjectival scales of greater numerical range: 0.105 to 0.0637 in the 3point scale and 0.048 to 0.473 in the 5-point scale. This assumption leads to assigning a disproportionately higher number of points to job posts which are higher in a given organization in comparison with low-hierarchy posts.

The methodic feature of the analytical key in this method distinguishing it from other techniques of job evaluation is the increase of numerical values of analytical evaluations in comparison with verbal evaluations according to the analytical form of an exponential function in the following form: 


$$
Y_{i}=\alpha_{0} \alpha_{1}^{X_{i}} \varepsilon_{i}
$$

with the below restrictions applied on parameters:

$$
\alpha_{0}>0, \alpha_{1}>0, \alpha_{1} \neq 1
$$

where: $Y_{i}-$ numerical values of verbal evaluations,

$\alpha_{0}, \alpha_{1}-$ model parameters,

$\mathrm{x}_{\mathrm{i}}-$ quantified verbal evaluations

$\varepsilon_{\mathrm{i}}-$ random deviation

The idea behind this method is exponential increase of numerical values of analytic values (intensity) in comparison with verbal evaluations. The aim of such action is to cause a strong, healthy competition between employees in a company working on different job posts. A post higher in the hierarchy of a company related to an analytic criterion is "rewarded" with higher exponential priority (weight) and numerical intensity of the criterion. However, it is not directly proportional to verbal evaluation. For example professional education $(\mathrm{Pi}=0.072)$ in comparison with vocational one $(\mathrm{Pi}=0.048)$ needs less intellectual effort than higher education $(\mathrm{Pi}=0.473)$ in comparison with vocational one $(\mathrm{Pi}=0.072)$. It seems to be obvious, but has not been really reflected in previous methods of job evaluation. An educated, experienced employee makes a greater contribution than an inexperienced one, thus the nonlinear "bonus" for the best employees in an organization.

Table 6. Example of numerical estimation on importance of verbal evaluation on a 5-point scale

\begin{tabular}{|c|c|c|c|c|c|c|}
\hline $\begin{array}{c}\text { Verbal } \\
\text { intensity }\end{array}$ & Very high & High & Average & Small & $\begin{array}{c}\text { Very } \\
\text { small }\end{array}$ & $\begin{array}{c}\text { Pi } \\
\text { (priority) }\end{array}$ \\
\hline Very high & 1 & 2 & 3 & 4 & 5 & 0.4174 \\
\hline High & $1 / 2$ & 1 & 2 & 3 & 4 & 0.2634 \\
\hline Average & $1 / 3$ & $1 / 2$ & 1 & 2 & 3 & 0.1602 \\
\hline Small & $1 / 4$ & $1 / 3$ & $1 / 2$ & 1 & 2 & 0.0975 \\
\hline Very small & $1 / 5$ & $1 / 4$ & $1 / 3$ & $1 / 2$ & 1 & 0.0615 \\
\hline Total & & & & & & $\mathbf{1 . 0 0 0 0}$ \\
\hline
\end{tabular}

Source: personal study

C.R. $=0.015$

Fig. 3. Numerical importance of evaluations for a 5-point scale 


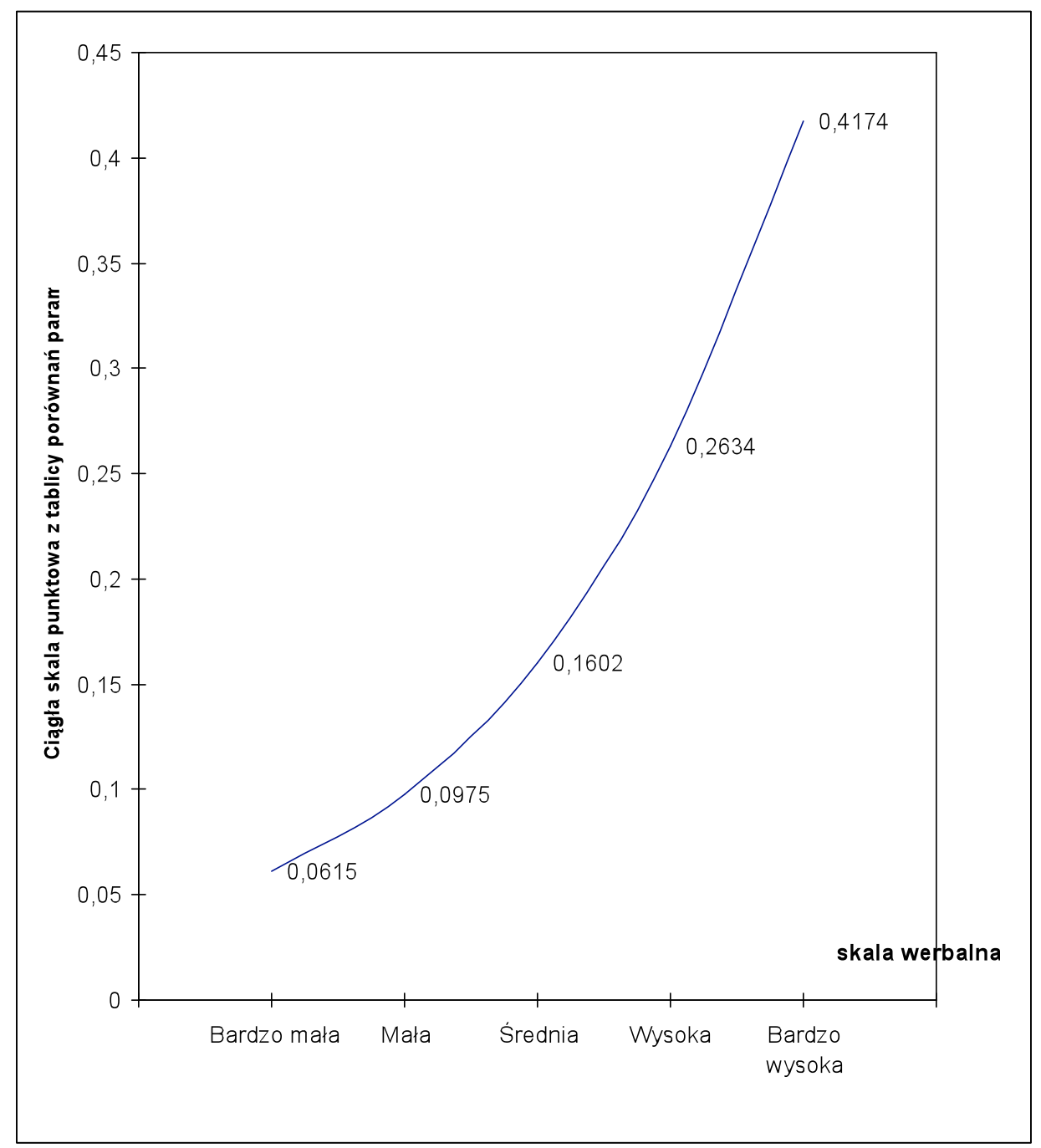

Source: personal study

\section{An integrated job evaluation system}

After choosing the main categories along with subcategories for job evaluation in an organization. The paired criteria concern all possible job posts in a given organization or job posts in a homogenous group of organizations e.g. civil service.

Verbal comparison of criteria may be done by using a specially designed table to mark the domination of individual criteria.

Such comparisons were made for all synthetic, analytical and fragmentary criteria. Verbal evaluations were changed into numerical ones 
(opinion quantification) by using the fundamental comparison scale of T. Saaty (see Table 2).

The calculations of numerical priorities for criteria and CR conformity rates were done by using a computer program entitled Expert Choice. The numerical priorities (weighs) of all criteria and CR conformity rates are presented in Table 8 below.

Table 8. An integrated job evaluation system, numerical priorities for criteria (examples)

\begin{tabular}{|c|c|c|c|c|}
\hline $\begin{array}{c}\text { Main criteria (synthetic) } \\
\text { and their priorities } \\
\text { (weights) } P_{s_{i}}\end{array}$ & $\begin{array}{l}\text { Sub-criteria (analytical } \\
\text { criteria) and their local } \\
\text { priorities (weights) } P_{a l_{i j}}\end{array}$ & $\begin{array}{c}\begin{array}{c}\text { Sub-criteria and } \\
\text { their global } \\
\text { priorities }\end{array} \\
P_{g_{i j}}=P_{s_{i}} \times P_{a l_{i j}}\end{array}$ & $\begin{array}{c}\text { Verbal intensity of the sub- } \\
\text { criteria }\end{array}$ & 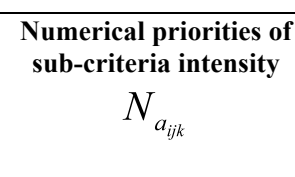 \\
\hline \multirow{20}{*}{$\begin{array}{l}\text { Know-how and skill } \\
P_{s_{i}}=0,335 \\
\mathrm{CR}=0.02\end{array}$} & \multirow{5}{*}{$\begin{array}{l}\text { Education } \\
P_{a l_{11}}=0,411\end{array}$} & \multirow{5}{*}{$P_{g_{11}}=0,138$} & Definitely below requirements & $N_{a_{111}}=0,048$ \\
\hline & & & Below requirements & $N_{a_{112}}=0,072$ \\
\hline & & & According to requirements & $N_{a_{113}}=0,144$ \\
\hline & & & Above requirements & $N_{a_{114}}=0,263$ \\
\hline & & & Definitely above requirements & $N_{a_{115}}=0,473$ \\
\hline & \multirow{5}{*}{$\begin{array}{l}\text { Professional know-how } \\
P_{a l_{12}}=0,188\end{array}$} & \multirow{5}{*}{$P_{g_{12}}=0,063$} & Low & $N_{a_{121}}=0,062$ \\
\hline & & & Below average & $N_{a_{122}}=0,097$ \\
\hline & & & Average & $N_{a_{123}}=0,160$ \\
\hline & & & Above average & $N_{a_{124}}=0,263$ \\
\hline & & & Exceptional & $N_{a_{125}}=0,417$ \\
\hline & \multirow{3}{*}{$\begin{array}{l}\text { Interpersonal skills } \\
P_{a l_{13}}=0,087\end{array}$} & \multirow{3}{*}{$P_{g_{13}}=0,029$} & Basic & $N_{a_{131}}=0,163$ \\
\hline & & & Important & $N_{a_{132}}=0,297$ \\
\hline & & & Essential & $N_{a_{133}}=0,540$ \\
\hline & \multirow{5}{*}{$\begin{array}{l}\text { Managerial } \quad \text { skills and } \\
\text { competence } P_{a l_{14}}=0,141\end{array}$} & \multirow{5}{*}{$P_{g_{14}}=0,047$} & Low & $N_{a_{141}}=0,048$ \\
\hline & & & Below standards & $N_{a_{142}}=0,072$ \\
\hline & & & According to standards & $N_{a_{143}}=0,144$ \\
\hline & & & Above standards & $N_{a_{144}}=0,263$ \\
\hline & & & Excellent & $N_{a_{145}}=0,473$ \\
\hline & \multirow{2}{*}{$\begin{array}{l}\text { Leadership skills and abilities } \\
P_{a l_{15}}=0,173\end{array}$} & \multirow{2}{*}{$P_{g_{15}}=0,058$} & Low & $N_{a_{151}}=0,062$ \\
\hline & & & Below average & $N_{a_{152}}=0,097$ \\
\hline
\end{tabular}




\begin{tabular}{|c|c|c|c|c|}
\hline $\begin{array}{c}\text { Main criteria (synthetic) } \\
\text { and their priorities } \\
\text { (weights) } P_{s_{i}}\end{array}$ & $\begin{array}{l}\text { Sub-criteria (analytical } \\
\text { criteria) and their local } \\
\text { priorities (weights) } P_{a l_{i j}}\end{array}$ & $\begin{array}{c}\begin{array}{c}\text { Sub-criteria and } \\
\text { their global } \\
\text { priorities }\end{array} \\
P_{g_{i j}}=P_{s_{i}} \times P_{a l_{i j}}\end{array}$ & $\begin{array}{c}\text { Verbal intensity of the sub- } \\
\text { criteria }\end{array}$ & $\begin{array}{c}\text { Numerical priorities of } \\
\text { sub-criteria intensity } \\
\qquad N_{a_{i j k}}\end{array}$ \\
\hline & & & Average & $N_{a_{153}}=0,160$ \\
\hline & & & Above average & $N_{a_{154}}=0,263$ \\
\hline & & & Exceptional & $N_{a_{155}}=0,417$ \\
\hline \multirow{17}{*}{$\begin{array}{l}\text { Experience } \\
P_{s_{2}}=0,202 \\
\mathrm{CR}=0.02\end{array}$} & \multirow{3}{*}{$\begin{array}{l}\text { No-experience work } \\
P_{a l_{21}}=0,062\end{array}$} & \multirow{3}{*}{$P_{g_{21}}=0,012$} & Poor & $N_{a_{211}}=0,163$ \\
\hline & & & Average & $N_{a_{212}}=0,297$ \\
\hline & & & Great & $N_{a_{213}}=0,540$ \\
\hline & \multirow{3}{*}{$\begin{array}{l}\text { General experience } \\
P_{a l_{22}}=0,097\end{array}$} & \multirow[t]{3}{*}{$P_{g_{22}}=0,020$} & Poor & $N_{a_{221}}=0,105$ \\
\hline & & & Average & $N_{a_{222}}=0,258$ \\
\hline & & & Great & $N_{a_{223}}=0,637$ \\
\hline & \multirow{3}{*}{$\begin{array}{l}\text { Complex work } \\
P_{a l_{23}}=0,160\end{array}$} & \multirow[t]{3}{*}{$P_{g_{23}}=0,032$} & Basic & $N_{a_{231}}=0,163$ \\
\hline & & & Important & $N_{a_{232}}=0,297$ \\
\hline & & & Essential & $N_{a_{233}}=0,540$ \\
\hline & \multirow{3}{*}{$\begin{array}{l}\text { Complicated work } \\
P_{a l_{24}}=0,263\end{array}$} & \multirow{3}{*}{$P_{g_{24}}=0,053$} & Basic & $N_{a_{241}}=0,163$ \\
\hline & & & Important & $N_{a_{242}}=0,297$ \\
\hline & & & Essential & $N_{a_{243}}=0,540$ \\
\hline & \multirow{5}{*}{$\begin{array}{l}\text { High technology } \\
P_{a l_{25}}=0,419\end{array}$} & \multirow{5}{*}{$P_{g_{25}}=0,085$} & Low & $N_{a_{251}}=0,048$ \\
\hline & & & Below standards & $N_{a_{252}}=0,072$ \\
\hline & & & According to standards & $N_{a_{253}}=0,144$ \\
\hline & & & Above standards & $N_{a_{254}}=0,263$ \\
\hline & & & Excellent & $N_{a_{255}}=0,473$ \\
\hline \multirow{7}{*}{$\begin{array}{l}\text { Wisdom } \\
P_{s_{3}}=0,047 \\
\mathrm{CR}=0.05\end{array}$} & \multirow{3}{*}{$\begin{array}{l}\text { Responsible use of know-how } \\
P_{a l_{31}}=0,511\end{array}$} & \multirow{3}{*}{$P_{g_{31}}=0,024$} & Poor & $N_{a_{311}}=0,105$ \\
\hline & & & Average & $N_{a_{312}}=0,258$ \\
\hline & & & Great & $N_{a_{313}}=0,637$ \\
\hline & \multirow{3}{*}{$\begin{array}{l}\text { Responsible use of experience } \\
P_{a l_{32}}=0,217\end{array}$} & \multirow{3}{*}{$P_{g_{32}}=0,010$} & Poor & $N_{a_{321}}=0,105$ \\
\hline & & & Average & $N_{a_{322}}=0,258$ \\
\hline & & & Great & $N_{a_{323}}=0,637$ \\
\hline & Responsible & & Poor & $N_{a_{331}}=0,105$ \\
\hline
\end{tabular}




\begin{tabular}{|c|c|c|c|c|}
\hline $\begin{array}{l}\text { Main criteria (synthetic) } \\
\text { and their priorities } \\
\text { (weights) } P_{s_{i}}\end{array}$ & $\begin{array}{l}\text { Sub-criteria (analytical } \\
\text { criteria) and their local } \\
\text { priorities (weights) } P_{a l_{i j}}\end{array}$ & 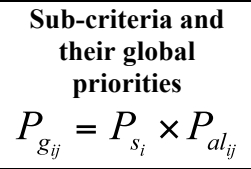 & $\begin{array}{c}\text { Verbal intensity of the sub- } \\
\text { criteria }\end{array}$ & $\begin{array}{c}\begin{array}{c}\text { Numerical priorities of } \\
\text { sub-criteria intensity }\end{array} \\
\qquad N_{a_{i j k}}\end{array}$ \\
\hline & \multirow{3}{*}{$\begin{array}{l}\text { information } \\
P_{a l_{33}}=0,127\end{array}$} & \multirow{3}{*}{$P_{g_{33}}=0,006$} & Poor & $N_{a_{331}}=0,105$ \\
\hline & & & Average & $N_{a_{332}}=0,258$ \\
\hline & & & Great & $N_{a_{333}}=0,637$ \\
\hline & \multirow{3}{*}{$\begin{array}{l}\text { Intellectual freedom and } \\
\text { independence } \\
P_{a l_{34}}=0,073\end{array}$} & \multirow{3}{*}{$P_{g_{34}}=0,004$} & Basic & $N_{a_{341}}=0,163$ \\
\hline & & & Important & $N_{a_{342}}=0,297$ \\
\hline & & & Essential & $N_{a_{343}}=0,540$ \\
\hline & \multirow{3}{*}{$\begin{array}{l}\text { Respect for one's own and } \\
\text { others' dignity } \\
P_{a l_{35}}=0,071\end{array}$} & \multirow{3}{*}{$P_{g_{35}}=0,003$} & Basic & $N_{a_{351}}=0,163$ \\
\hline & & & Important & $N_{a_{352}}=0,297$ \\
\hline & & & Essential & $N_{a_{353}}=0,540$ \\
\hline \multirow{15}{*}{$\begin{array}{l}\text { Physical and mental effort } \\
P_{s_{4}}=0,059 \\
\mathrm{CR}=0.05\end{array}$} & \multirow{3}{*}{$\begin{array}{l}\text { Energy } \\
P_{a l_{41}}=0,382\end{array}$} & \multirow{3}{*}{$P_{g_{41}}=0,021$} & Low & $N_{a_{411}}=0,163$ \\
\hline & & & Average & $N_{a_{412}}=0,297$ \\
\hline & & & High & $N_{a_{413}}=0,540$ \\
\hline & \multirow{3}{*}{$\begin{array}{l}\text { Initiative } \\
P_{a l_{42}}=0,078\end{array}$} & \multirow{3}{*}{$P_{g_{42}}=0,005$} & Low & $N_{a_{421}}=0,163$ \\
\hline & & & Average & $N_{a_{422}}=0,297$ \\
\hline & & & High & $N_{a_{423}}=0,540$ \\
\hline & \multirow{3}{*}{$\begin{array}{l}\text { Dexterity } \\
P_{a l_{43}}=0,121\end{array}$} & \multirow{3}{*}{$P_{g_{43}}=0,007$} & Low & $N_{a_{431}}=0,163$ \\
\hline & & & Average & $N_{a_{432}}=0,297$ \\
\hline & & & High & $N_{a_{433}}=0,540$ \\
\hline & \multirow{3}{*}{$\begin{array}{l}\text { Precision } \\
P_{a l_{44}}=0,173\end{array}$} & \multirow{3}{*}{$P_{g_{44}}=0,010$} & Low & $N_{a_{441}}=0,163$ \\
\hline & & & Average & $N_{a_{442}}=0,297$ \\
\hline & & & High & $N_{a_{443}}=0,540$ \\
\hline & \multirow{3}{*}{$\begin{array}{l}\text { Work environment } \\
P_{a l_{45}}=0,266\end{array}$} & \multirow{3}{*}{$P_{g_{45}}=0,016$} & Below average & $N_{a_{451}}=0,163$ \\
\hline & & & Average & $N_{a_{452}}=0,297$ \\
\hline & & & Above average & $N_{a_{453}}=0,540$ \\
\hline \multirow{3}{*}{$\begin{array}{l}\text { Intellectual effort } \\
P_{s_{5}}=0,190 \\
\mathrm{CR}=0.03\end{array}$} & \multirow{3}{*}{$\begin{array}{l}\text { Creativity } \\
P_{a l_{51}}=0,201\end{array}$} & \multirow{3}{*}{$P_{g_{51}}=0,038$} & Poor & $N_{a_{511}}=0,105$ \\
\hline & & & Average & $N_{a_{512}}=0,258$ \\
\hline & & & Great & $N_{a_{513}}=0,637$ \\
\hline
\end{tabular}




\begin{tabular}{|c|c|c|c|c|}
\hline $\begin{array}{c}\text { Main criteria (synthetic) } \\
\text { and their priorities } \\
\text { (weights) } P_{s_{i}}\end{array}$ & $\begin{array}{l}\text { Sub-criteria (analytical } \\
\text { criteria) and their local } \\
\text { priorities (weights) } P_{a l_{i j}}\end{array}$ & $\begin{array}{c}\begin{array}{c}\text { Sub-criteria and } \\
\text { their global } \\
\text { priorities }\end{array} \\
P_{g_{i j}}=P_{s_{i}} \times P_{a l_{i j}}\end{array}$ & $\begin{array}{c}\text { Verbal intensity of the sub- } \\
\text { criteria }\end{array}$ & $\begin{array}{c}\text { Numerical priorities of } \\
\text { sub-criteria intensity } \\
\qquad N_{a_{i j k}}\end{array}$ \\
\hline & \multirow{3}{*}{$\begin{array}{l}\text { Innovation } \\
P_{a l_{52}}=0,152\end{array}$} & \multirow{3}{*}{$P_{g_{52}}=0,029$} & Poor & $N_{a_{521}}=0,105$ \\
\hline & & & Average & $N_{a_{522}}=0,258$ \\
\hline & & & Great & $N_{a_{523}}=0,637$ \\
\hline & \multirow{3}{*}{$\begin{array}{l}\text { Resourcefulness } \\
P_{a l_{53}}=0,323\end{array}$} & \multirow{3}{*}{$P_{g_{53}}=0,061$} & Poor & $N_{a_{531}}=0,105$ \\
\hline & & & Average & $N_{a_{532}}=0,258$ \\
\hline & & & Great & $N_{a_{533}}=0,637$ \\
\hline & \multirow{3}{*}{$\begin{array}{l}\text { Emotionality and stress } \\
P_{a l_{54}}=0,042\end{array}$} & \multirow{3}{*}{$P_{g_{54}}=0,008$} & Below average & $N_{a_{541}}=0,163$ \\
\hline & & & Average & $N_{a_{542}}=0,297$ \\
\hline & & & Above average & $N_{a_{543}}=0,540$ \\
\hline & \multirow{3}{*}{$\begin{array}{l}\text { Aim attainability } \\
P_{a l_{55}}=0,191\end{array}$} & \multirow{3}{*}{$P_{g_{55}}=0,036$} & Low & $N_{a_{551}}=0,163$ \\
\hline & & & Average & $N_{a_{552}}=0,297$ \\
\hline & & & High & $N_{a_{553}}=0,540$ \\
\hline & \multirow{3}{*}{$\begin{array}{l}\text { Pioneering and visionary } \\
\text { imagination } \\
P_{a l_{56}}=0,091\end{array}$} & \multirow{3}{*}{$P_{g_{56}}=0,017$} & Poor & $N_{a_{561}}=0,105$ \\
\hline & & & Good & $N_{a_{562}}=0,258$ \\
\hline & & & Excellent & $N_{a_{563}}=0,637$ \\
\hline \multirow{12}{*}{$\begin{array}{l}\text { Responsibilities } \\
P_{s_{6}}=0,106 \\
\mathrm{CR}=0.04\end{array}$} & \multirow{3}{*}{$\begin{array}{l}\text { Taking decisions } \\
P_{a l_{61}}=0,145\end{array}$} & \multirow{3}{*}{$P_{g_{61}}=0,015$} & Poor & $N_{a_{611}}=0,105$ \\
\hline & & & Average & $N_{a_{612}}=0,258$ \\
\hline & & & Great & $N_{a_{613}}=0,637$ \\
\hline & \multirow{3}{*}{$\begin{array}{l}\text { People } \\
P_{a l_{62}}=0,336\end{array}$} & \multirow{3}{*}{$P_{g_{62}}=0,036$} & Poor & $N_{a_{621}}=0,105$ \\
\hline & & & Average & $N_{a_{622}}=0,258$ \\
\hline & & & Great & $N_{a_{623}}=0,637$ \\
\hline & \multirow{3}{*}{$\begin{array}{l}\text { Finances } \\
P_{a l_{63}}=0,082\end{array}$} & \multirow{3}{*}{$P_{g_{63}}=0,009$} & Below average & $N_{a_{631}}=0,163$ \\
\hline & & & Average & $N_{a_{632}}=0,297$ \\
\hline & & & Above average & $N_{a_{633}}=0,540$ \\
\hline & \multirow{3}{*}{$\begin{array}{l}\text { Property } \\
P_{a l_{64}}=0,086\end{array}$} & \multirow{3}{*}{$P_{g_{64}}=0,009$} & Low & $N_{a_{641}}=0,163$ \\
\hline & & & Average & $N_{a_{642}}=0,297$ \\
\hline & & & High & $N_{a_{643}}=0,540$ \\
\hline
\end{tabular}




\begin{tabular}{|c|c|c|c|c|}
\hline $\begin{array}{l}\text { Main criteria (synthetic) } \\
\text { and their priorities } \\
\text { (weights) } P_{s_{i}}\end{array}$ & $\begin{array}{l}\text { Sub-criteria (analytical } \\
\text { criteria) and their local } \\
\text { priorities (weights) } P_{a l_{i j}}\end{array}$ & $\begin{array}{c}\begin{array}{c}\text { Sub-criteria and } \\
\text { their global } \\
\text { priorities }\end{array} \\
P_{g_{i j}}=P_{s_{i}} \times P_{a l_{i j}}\end{array}$ & $\begin{array}{c}\text { Verbal intensity of the sub- } \\
\text { criteria }\end{array}$ & $\begin{array}{c}\text { Numerical priorities of } \\
\text { sub-criteria intensity } \\
\qquad N_{a_{i j k}}\end{array}$ \\
\hline & \multirow{3}{*}{$\begin{array}{l}\text { Moral values } \\
P_{a l_{65}}=0,069\end{array}$} & \multirow{3}{*}{$P_{g_{65}}=0,007$} & Low & $N_{a_{651}}=0,163$ \\
\hline & & & Average & $N_{a_{652}}=0,297$ \\
\hline & & & High & $N_{a_{653}}=0,540$ \\
\hline & \multirow{3}{*}{$\begin{array}{ll}\text { Production, } & \text { Services, } \\
\text { Marketing } & \\
P_{a l_{66}}=0,282 & \end{array}$} & \multirow{3}{*}{$P_{g_{66}}=0,030$} & Low & $N_{a_{661}}=0,163$ \\
\hline & & & Average & $N_{a_{662}}=0,297$ \\
\hline & & & High & $N_{a_{663}}=0,540$ \\
\hline \multirow{18}{*}{$\begin{array}{l}\text { Cooperation } \\
P_{s_{7}}=0,0162 \\
\mathrm{CR}=0.03\end{array}$} & \multirow{3}{*}{$\begin{array}{l}\text { Mobility } \\
P_{a l_{71}}=0,288\end{array}$} & \multirow{3}{*}{$P_{g_{71}}=0,018$} & Poor & $N_{a_{711}}=0,105$ \\
\hline & & & Average & $N_{a_{712}}=0,258$ \\
\hline & & & Great & $N_{a_{713}}=0,637$ \\
\hline & \multirow{3}{*}{$\begin{array}{l}\text { Communication } \\
P_{a l_{72}}=0,258\end{array}$} & \multirow{3}{*}{$P_{g_{72}}=0,016$} & Poor & $N_{a_{721}}=0,105$ \\
\hline & & & Average & $N_{a_{722}}=0,258$ \\
\hline & & & Great & $N_{a_{723}}=0,637$ \\
\hline & \multirow{3}{*}{$\begin{array}{l}\text { Motivation } \\
P_{a l_{73}}=0,164\end{array}$} & \multirow{3}{*}{$P_{g_{73}}=0,010$} & Poor & $N_{a_{731}}=0,105$ \\
\hline & & & Average & $N_{a_{732}}=0,258$ \\
\hline & & & Great & $N_{a_{733}}=0,637$ \\
\hline & \multirow{3}{*}{$\begin{array}{l}\text { Negotiations } \\
P_{a l_{74}}=0,109\end{array}$} & \multirow{3}{*}{$P_{g_{74}}=0,007$} & Poor & $N_{a_{741}}=0,105$ \\
\hline & & & Average & $N_{a_{742}}=0,258$ \\
\hline & & & Great & $N_{a_{743}}=0,637$ \\
\hline & \multirow{3}{*}{$\begin{array}{l}\text { Tact and diplomacy } \\
P_{a l_{75}}=0,072\end{array}$} & \multirow{3}{*}{$P_{g_{75}}=0,004$} & Basic & $N_{a_{751}}=0,163$ \\
\hline & & & Important & $N_{a_{752}}=0,297$ \\
\hline & & & Essential & $N_{a_{753}}=0,540$ \\
\hline & \multirow{3}{*}{$\begin{array}{l}\text { Awareness of basic values } \\
P_{a l_{76}}=0,109\end{array}$} & \multirow{3}{*}{$P_{g_{76}}=0,007$} & Basic & $N_{a_{761}}=0,163$ \\
\hline & & & Important & $N_{a_{762}}=0,297$ \\
\hline & & & Essential & $N_{a_{763}}=0,540$ \\
\hline
\end{tabular}

Source: personal study

When analyzing Table 8 above, it is clear that there is a great diversity between weights of main criteria (synthetic), as well as subcriteria (analytic criteria). 
By comparing in pairs synthetic criteria, we have arrived at range of weights from 0.047 (Wisdom) to 0.336 (Know-how and skills). CR conformity rate for comparisons was established between 0.02 and 0.07 . According to the recommendations of T. Saaty, the creator of AHP, these values were inside the error limits. Weights assigned to criteria correlate with their relative value in the evaluated jobs. Previously these weights in methods described earlier were ascribed equally to all synthetic criteria or were selected discretionary on the basis of knowledge about a given job rarely were they the result of a statistical analysis (correlation or simple regression). Assuming the equivalence of all 7 synthetic criteria, we would end up with weight quantities for each criterion equaling to: $(1: 7=$ 0.143). After internally juxtaposing analytical criteria and comparing them then to synthetic criteria, we have achieved "local" weights for each sub-criterion. The estimated weights for analytical criteria are related to the "local" synthetic criterion. This is why the weights of these criteria are so diversified in comparison to main criteria. In order to relate each subcriterion to the total value of an evaluated post, "global" weights were calculated earlier by means of a formula presented earlier. Their value is assigned as a percentage share of a given sub-criterion in the value of an evaluated job. These values range from 0.003 (respect for dignity) to 0.138 (education). Assuming, similarly as we did for main criteria, that all 38 analyzed analytical criteria are equal, the weight value assigned to each criterion would amount to: $(1: 38=0.026)$.

The next stage in the proposed method is a verbal description of all job posts. Description is based on a 3-point or 5-point verbal adjectival scale defining the intensity of 38 analytical criteria assigned to a given job.

After assessing the global priority of a given analytical criterion taken out of Table 8 with its intensity also from Table 8 , we can easily determine the value of a job post through the following formula:

$$
W_{s_{i}}=\sum_{j=1}^{n}\left(P_{g_{i j}} \times N_{a_{i j k}} \times 10000\right)
$$

For example let us determine job value for two people: a company manager and a truck driver. The results are given in Table 9 below.

Table 9. An example of job evaluation with points 


\begin{tabular}{|c|c|c|c|c|c|c|c|}
\hline \multirow[b]{2}{*}{ Job description } & \multirow{2}{*}{$\begin{array}{c}P_{g_{i j}} \text { global } \\
\text { weight of } \\
\text { the } \\
\text { criterion }\end{array}$} & \multicolumn{3}{|c|}{ Company manager } & \multicolumn{3}{|c|}{ Truck driver } \\
\hline & & $\begin{array}{c}\text { Verbal } \\
\text { intensity of } \\
\text { sub-criteria }\end{array}$ & $\begin{array}{c}\text { Numerical } \\
\text { intensity } \\
N_{a_{i j k}}\end{array}$ & $P_{g_{i j}} \times N_{a_{i j k}}$ & $\begin{array}{c}\text { Verbal } \\
\text { intensity of } \\
\text { sub-criteria }\end{array}$ & $\begin{array}{c}\text { Numerical } \\
\text { intensity } \\
N_{a_{i j k}}\end{array}$ & $P_{g_{i j}} \times N_{a_{i j k}}$ \\
\hline Education & 0.138 & $\begin{array}{c}\text { Definitely } \\
\text { above average }\end{array}$ & 0.473 & 0.0653 & Below standard & 0.072 & 0.0099 \\
\hline $\begin{array}{l}\text { Professional know- } \\
\text { how }\end{array}$ & 0.063 & Above average & 0.263 & 0.0166 & Average & 0.160 & 0.0101 \\
\hline Interpersonal skills & 0.029 & Essential & 0.540 & 0.0157 & Basic & 0.163 & 0.0047 \\
\hline $\begin{array}{l}\text { Managerial skills and } \\
\text { competence }\end{array}$ & 0.047 & Excellent & 0.473 & 0.0222 & Low & 0.048 & 0.0022 \\
\hline $\begin{array}{l}\begin{array}{l}\text { Leadership skills and } \\
\text { abilities }\end{array} \\
\end{array}$ & 0.058 & Above average & 0.263 & 0.152 & Low & 0.062 & 0.0036 \\
\hline No-experience work & 0.012 & Average & 0.297 & 0.0036 & Average & 0.297 & 0.0036 \\
\hline General experience & 0.020 & Great & 0.637 & 0.0127 & Average & 0.258 & 0.0052 \\
\hline Complex work & 0.032 & Essential & 0.540 & 0.0173 & Important & 0.297 & 0.0095 \\
\hline Complicated work & 0.053 & Essential & 0.540 & 0.0286 & Important & 0.297 & 0.0157 \\
\hline High technology & 0.085 & Above average & 0.263 & 0.0224 & Low & 0.062 & 0.0053 \\
\hline $\begin{array}{l}\text { Responsible use of } \\
\text { know-how }\end{array}$ & 0.024 & Great & 0.637 & 0.0153 & Average & 0.258 & 0.0062 \\
\hline $\begin{array}{l}\begin{array}{l}\text { Responsible use of } \\
\text { experience }\end{array} \\
\end{array}$ & 0.010 & Average & 0.258 & 0.0026 & Average & 0.258 & 0.0026 \\
\hline $\begin{array}{l}\text { Responsible use of } \\
\text { information }\end{array}$ & 0.006 & Great & 0.637 & 0.0038 & Poor & 0.105 & 0.0006 \\
\hline $\begin{array}{l}\text { Intellectual freedom } \\
\text { and independence }\end{array}$ & 0.004 & Essential & 0.540 & 0.0022 & Basic & 0.163 & 0.0006 \\
\hline $\begin{array}{l}\text { Respect for one's own } \\
\text { and others' dignity }\end{array}$ & 0.003 & Essential & 0.540 & 0.0016 & Important & 0.297 & 0.0009 \\
\hline Energy & 0.021 & Small & 0.163 & 0.0034 & High & 0.540 & 0.0113 \\
\hline Initiative & 0.005 & High & 0.540 & 0.0027 & Small & 0.163 & 0.0008 \\
\hline Dexterity & 0.007 & Small & 0.163 & 0.0011 & Average & 0.297 & 0.0021 \\
\hline Precision & 0.010 & High & 0.570 & 0.0057 & High & 0.540 & 0.0054 \\
\hline Work environment & 0.016 & Average & 0.297 & 0.0048 & Average & 0.297 & 0.0048 \\
\hline Creativity & 0.038 & Great & 0.637 & 0.0242 & Poor & 0.105 & 0.0040 \\
\hline Innovation & 0.029 & Great & 0.637 & 0.0185 & Poor & 0.105 & 0.0030 \\
\hline Resourcefulness & 0.061 & Great & 0.637 & 0.0388 & Poor & 0.105 & 0.0064 \\
\hline Emotionality and stress & 0.008 & Above average & 0.540 & 0.0043 & Above average & 0.540 & 0.0043 \\
\hline Aim attainability & 0.036 & High & 0.540 & 0.0194 & Small & 0.163 & 0.0059 \\
\hline $\begin{array}{l}\text { Pioneering and } \\
\text { visionary imagination }\end{array}$ & 0.017 & Excellent & 0.637 & 0.0108 & Poor & 0.105 & 0.0018 \\
\hline $\begin{array}{ll}\text { Responsibility } & \text { for } \\
\text { taking decisions } & \\
\end{array}$ & 0.015 & Great & 0.637 & 0.0096 & Poor & 0.105 & 0.0016 \\
\hline $\begin{array}{ll}\text { Responsibility } & \text { for } \\
\text { people } & \end{array}$ & 0.036 & Great & 0.637 & 0.0229 & Poor & 0.105 & 0.0038 \\
\hline $\begin{array}{l}\text { Responsibility for } \\
\text { finances }\end{array}$ & 0.009 & Above average & 0.540 & 0.0049 & Below average & 0.163 & 0.0015 \\
\hline $\begin{array}{l}\text { Responsibility for } \\
\text { property }\end{array}$ & 0.009 & High & 0.540 & 0.0049 & Average & 0.297 & 0.0027 \\
\hline $\begin{array}{l}\text { Responsibility for } \\
\text { moral values }\end{array}$ & 0.007 & High & 0.540 & 0.0038 & Small & 0.163 & 0.0011 \\
\hline $\begin{array}{lr}\text { Responsibility } & \text { for } \\
\text { production, } & \text { services } \\
\text { and marketing } & \\
\end{array}$ & 0.030 & High & 0.540 & 0.0162 & Small & 0.163 & 0.0049 \\
\hline Mobility & 0.018 & Great & 0.637 & 0.0115 & Great & 0.637 & 0.0115 \\
\hline Communication & 0.016 & Great & 0.637 & 0.0102 & Poor & 0.105 & 0.0017 \\
\hline Motivation & 0.010 & Great & 0.637 & 0.0064 & Average & 0.258 & 0.0026 \\
\hline Negotiations & 0.007 & Great & 0.637 & 0.0045 & Poor & 0.105 & 0.0007 \\
\hline Tact and diplomacy & 0.004 & Essential & 0.540 & 0.0022 & Basic & 0.163 & 0.0006 \\
\hline
\end{tabular}




\begin{tabular}{|l|c|c|c|c|c|c|c|}
\hline $\begin{array}{l}\text { Awareness of basic } \\
\text { values }\end{array}$ & 0.007 & Essential & 0.540 & 0.0038 & Basic & 0.163 \\
\hline Total & $\mathbf{1 . 0 0 0}$ & $\mathbf{X}$ & $\mathbf{X}$ & $\mathbf{0 . 4 7 9 7}$ & $\mathbf{X}$ & $\mathbf{X}$ \\
\hline
\end{tabular}

Point value of a company manager:

$$
\begin{gathered}
W_{s_{i}}=0,4797 \times 10000 \\
W_{s_{i}}=4797
\end{gathered}
$$

Point value of a truck driver:

$$
\begin{gathered}
W_{s_{2}}=0,1643 \times 10000 \\
W_{s_{2}}=1643
\end{gathered}
$$

For further calculation, we assumed that 1 point is worth $\mathrm{P}=\mathrm{PLN} 2$.

Fiscal value of a company manager:

$$
\begin{gathered}
V_{f s_{i}}=W_{s_{i}} \times P \\
V_{f s_{i}}=4797 \times 2 P L N \\
V_{f_{s_{i}}}=9594 P L N
\end{gathered}
$$

Fiscal value of a truck driver:

$$
\begin{gathered}
V_{f s_{2}}=W_{s_{2}} \times P \\
V_{f s_{2}}=1643 \times 2 P L N \\
V_{f s_{2}}=3286 P L N
\end{gathered}
$$

The calculations above show that the value of the post of a company manger is almost three times greater than the post of a truck driver.

Depending on the specifications of an organization, as well as other factors presented earlier, the number of criteria may be decreased to just a dozen or so, especially when it comes to small and medium companies. One of the most crucial elements of job evaluation in organizations is an objective verbal description of posts. Its quantification is particularly easy when the process is supported by a computer calculation program.

\section{Conclusions}

Job evaluation is a constant, systematic process and a vital part of a modern organization management. It allows assessing work requirements for every job post together with its relative value. The aim of this paper was to establish a method fulfilling the above statement.

A detailed analysis of job evaluation process enabled us to appreciate the immense complexity of the issue and helped to incorporate different connections 
and relations, as well as ascribing each criterion a weigh - a numerical priority. It was all possible due to the trailblazing use a multicriterial problem solution method AHP (Analytic Hierarchy Process) of Prof. T. Saaty.

The established method is unique in comparison to other techniques in the following features:

i) In contrast to other point and analytical methods, here the relations between studied factors are non-linear - similarly to the real world,

ii) The increase of numerical values of analytical criteria in comparison to verbal evaluations has the form of an exponential function,

iii) The final weight (priority, intensity) for a given analytical factor is a multiplicative quantity, translating the value from synthetic to analytical criteria and further to points describing the evaluated job post (intensity). This way a certain continuity (progress) in job evaluation was provided,

iv) The method is based on strong mathematical elements of a multicriterial problem solution method AHP of T. Saaty,

v) The method is based on cognitive psychology - meaning that all input data are psychologically unanimous,

vi) In spit of basing itself on human judgments, the method is largely objective, thus it will be received by many as fair, fulfilling the main demand of job evaluation,

vii) The method is free of any discrimination on grounds of sex, race, ethnicity etc.

viii) The method fulfills requirements of legal regulations concerning equal remuneration,

ix) The method is flexible enough to create new groups of job posts,

$\mathrm{x}$ ) It is possible to use the presented method - the integrated system of job evaluation to all job posts in a given organization,

xi) The possibility of smooth transition from job evaluation to diversification of remuneration in terms of individual results and competence of an employee, as well as changing internal and external factors in an organization,

xii) The established method is universal; meaning that by using it one can evaluate different types of jobs - production, services, administrative and managerial. Furthermore, it includes whole companies and may be used in different companies, cultures, societies and countries,

xiii) Basing this method of job evaluation on cognitive psychology and applied mathematics gives new opportunities to human resource management in organizations.

\section{Bibliography}

Adamus W. (edit.): The Analytic Hierarchy \& Network Processes. Application in Solving Multicriteria Decision Problems. Jagiellonian University, Kraków 2008. 
Adamus W., Gręda A.: Wspomaganie decyzji wielokryterialnych $w$ rozwiąywaniu wybranych problemów organizacyjnych $i$ menedżerskich. Badania Operacyjne i Decyzje, Nr 2, s.5-37, 2005.

Armstrong M., Cummins A., Hastings S., Wood W.: Wartościowanie stanowisk pracy. Oficyna a Wolters Kluwer business, Kraków 2008.

Armstrong M.: Zarzadzanie zasobami ludzkimi, wyd. 3 poszerzone, Oficyna Ekonomiczna, Kraków 2005.

Banfield P., Kay R.: Introduction to Human Resource Management, Oxford University Press, New York, 2008

Baszyński A.: Ile za jeden punkt. Personel, nr 13/14, 2000.

Blumenthal A. L.: The Process of Cognition, Prentice-Hall, Inc., Englewood Cliffs, New Jersey 1977.

Borkowska S.: Strategie wynagrodzeń, Oficyna Ekonomiczna, Kraków 2006.

Czajka Z., Jacukowicz Z., Juchnowicz M.: Wartościowanie pracy a zarządzanie płacami. Difin, Warszawa 1998.

Erev I., Cohen B.: Verbal versus numerical probabilities: Efficiency, biased, and the preference paradox. Organizational Behavior and Human Decision Processes, 5:1-18, 1990.

Gugała K.: Wartościowanie stanowisk. Personel, nr 2, 1998.

Jachnowicz M.: Wartościowanie pracy a polityka płac. Instytut Wydawniczy Związków Zawodowych, Warszawa 1988.

Jacukowicz Z.: Jak to robia w Unii? Personel, nr 7/8, 1999.

Jacukowicz Z.: Praca i jej opłacanie, Ośrodek Doradztwa i Doskonalenia Kadr, Gdańsk 2002.

Juchnowicz M., Sienkiewicz L.: Jak oceniać pracę? Wartość stanowiska $i$ kompetencji, Difin, Warszawa 2006.

Kabaj M.: (red.) Metody wartościowania pracy, PWE, Warszawa 1979.

Kahneman D., Slovic P., Tversky A. (editors): Judgment under Uncertainty: Heuristics and Biases. Cambridge University Press, Cambridge, 1982.

Kocój M., i in.: Określenie relatywnej wartości stanowisk pracy w zakresie opieki zdrowotnej metoda UMEWAP-95 na przyktadzie Samodzielnego Publicznego Zaktadu Opieki Zdrowotnej w Przeworsku, Antidotum, nr 7, 2000.

Kopertyńska W.: Od oceny do wyceny, Personel, nr 1, 1996.

Król H., Ludwiczyński A. (ed.): Zarządzanie Zasobami Ludzkimi, Wydawnictwo Naukowe PWN, Warszawa 2006. 
Kwiecień K., (Ernest \& Young): Czy wartościowanie stanowisk pracy jest konieczne, aby zbudować motywacyjny system wynagrodzeń zasadniczych? artykuł zamieszczony na stronie http://www.kadry.info.pl z dnia 2004-11-01.

Larichev O., I., Moshkovich H. M., Rebrik S.B.: Systematic research into human behavior in multiattribute object classification problems. Acta Psychologica, 68: 171-182, 1998.

Larichev O. I.: Psychological validation of decision methods. Journal of Applied Systems Analysis, No 11, pp. 37-46, 1984.

Larichev O.I., Moshkovich H. M.: Verbal Decision Analysis for Unstruktured Problems. Kluwer Academic Publishers, Boston, 1997.

Martyniak Z.: Metodologia wartościowania pracy, Antykwa, Kraków 1998.

Miller H. A.: The Magical Number Seven, Plus or Minus Two: Some Limits on Our Capacity for Processing Information, Vol. 63, No. 2, 81-97, 1956.

Moshkovich H.M., Mechitov A. L., Olson D.L.: Verbal Decision Analysis [in:] Multiple Criteria Decision Analysis: State of the Art Surveys, edited by J. Figueria, S. Greco, M. Ehrgott, Springer, pp. 609-637, 2005

Neumann Management Institute: Wartościowanie stanowisk czy kompetencji?, artykuł zamieszczony na stronie http://studenci.pl z dnia 2004.11.02.

Oleksyn T.: Praca $i$ płace $w$ zarzadzaniu. wyd. Międzynarodowej Szkoły Menedżerów, Warszawa 2001.

Pocztowski A.: Zarządzanie zasobami ludzkimi, PWE Warszawa 2003.

Poels F.: Wartościowanie stanowisk pracy i strategie wynagrodzeń - jak wprowadzać efektywny system, Oficyna Wydawnictw Ekonomicznych, Kraków 2000.

Ratajczyk Z.: Elementy psychologii pracy, Uniwersytet Śląski, Katowice 1991.

Rosa M.: Szacowanie stanowisk i kompetencji, artykuł zamieszczony na stronie http://www.personel.infor.pl, z dnia 2004.11.02.

Rostkowski T., Zieliński W.: Z biznesu do stużby cywilnej (4). Proces wartościowania stanowisk pracy $w$ urzędzie. Personel i Zarządzanie nr 2, s. 4043, 2008.

Rypina E., Rostkowski T.: Z biznesu do stużby cywilnej (3). Kryteria wartościowania stanowisk pracy. Personel i Zarządzanie nr 1, s. 12-17, 2008.

Saaty T. L.: Decision Making with Dependence and Feedback, The Analytic Network Process, RWS Publications, Pittsburgh, PA, 2001.

Saaty T. L.: Fundamentals of Decision Making and Priority Theory with the Analytic Hierarchy Process, Vol. VI of the AHP Series, Pittsburgh: RSW Publications, 2006. 
Simon H.: The New Science of Management Decision. Haper and Row, New York, 1960.

Stelewski T., Chlebicka E. (red.): Zarządzanie zasobami ludzkimi. Wybrane problemy i metody. Oficyna Wydawnicza Politechniki Wrocławskiej, Wrocław 1997.

Strzelecki T.: Oceny punktowe wartościowania pracy. Technika Sulzera. Przegląd Organizacji, nr 8, 1976.

Świątkiewicz-Zych H.: Eksperymentalne wykorzystanie wartościowania pracy dla celów płacowych przedsiębiorstwa. Ekonomika i Organizacja Pracy, nr 3, 1984.

Tversky A.: Elimination by aspects: A probabilistic theory of choice, Michigan Mathematical Psychology Program MMP 71-12. The University of Michigan. Ann Arbor., Michigan 1971.

Wartościowanie stanowisk pracy w stużbie cywilnej - poradnik. Kancelaria Prezesa Rady Ministrów. Departament Służby Cywilnej. Warszawa 2007.

Wójcik M.: Każdemu wedtug wartości, Personel, nr 10, 1999.

Zarzadzanie Zasobami Ludzkimi. Humanizacja Pracy, nr 1-2, 2000. 


\section{A New Method of Job Evaluation Wiktor Adamus Jagiellonian University \\ wiktor.adamus@uj.edu.pl Abstract}

A cynic is one who knows all the prices without knowing the value

Oscar Wilde

Job within organization can be discussed in the context of its quantity possible to do, quality resulting from its difficulty level and effect achieved by the employee that is effects of his work. To measure job from a quantitative point of view we use work norms as a function of time standards, products quantity or service level.

It is much more difficult to measure qualitative job parameters than measuring quantity of job and its effects. In the literature we know several methods to job evaluation. However, none of them determines precisely the value of individual job evaluation within organization. The paper aims to develop a new method to measure and assess qualitative parameters of job in a simple, transparent, universal and timeless way. When evaluating a given feature, factor, object, subject we weight various quality and quantity criteria relative to an accepted pattern or value in a given organization, society or culture.

Weight (priorities) determined based on comparisons designate relative value of a comparative factor. Building a system of job evaluation in the organization 7. synthetic criteria were taken: knowledge, experience, wisdom, psychological and physical effort, intellectual effort, responsibility and cooperation. Each synthetic criterion was given a few analytical criteria, which in turn was assigned a verbal, adjective level of intensity. To solve the problem we used a multicriterial problem solution method AHP (Analytic Hierarchy Process). By pairwise comparison of each synthetic criteria (on a verbal scale) in relation to job quality in the Saaty's fundamental scale we arrived a weight comparison matrix (priorities) within the range $[>0,<1]$. A sum of weights from comparisons of all synthetic criteria is equal to one. Next, the same scale was used for comparisons of analytical criteria (sub-criteria) and their values in relation to particular synthetic criteria. Each analytical criterion was given weight (priority) resulting from comparisons, their total sum for each synthetic criterion is also equal to one. Next, each analytical sub-criterion in the system of work quality assessment was assigned adjectival level of intensity, also in a numerical scale calculated from a matrix of verbal adjectival comparison scale. The sum of those weights is also equal to 1 . 
Our method differs form all its predecessors by the fact that a final weight (priority) for a given analytical factor is a multiplicative value transferring values from synthetic criteria onto analytical, those in turn into point assessments. Certain interdependencies between factors examined are not linear, just like in a real world.

Number of points for each work position is calculated as follows:

$$
W_{S_{i}}=\sum_{k=1}^{n}\left(P_{s_{i}} \times P_{a_{i j}} \times N_{a_{i j k}}\right)
$$

where:

$W_{s_{i}}$ - point value of i-position,

$P_{s_{i}}$ - weight (priority) of j-synthetic criterion,

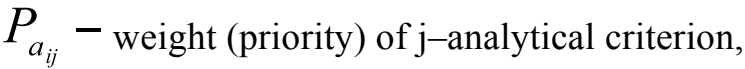

$N_{a_{i j k}}$ - weight (priority) k-intensity in j-analytical criterion.

Having all the numerical values for all synthetic, analytical criteria and analytical intensity sub-criteria, we calculated point values of hundreds of possible work positions in various enterprises. All those values were aggregated in matrices (tables). The method developed has a universal value in the sense, that with its use the job that can be valued can be directly manufacturing (service) as well as indirect - managerial or administrative. Moreover it can be used in various organizations, cultures, societies or states.

The method is well grounded in cognitive psychology, applied mathematics and computer science.

\section{About the author}

Prof. Wiktor Adamus, PhD Eng., head of the Quantity Methods Unit at the Social Management and Communication Department of the Jagiellonian University, and also head of the Praxeological Management and Education Unit on the Economy and Management Department of the Andrzej Frycz Modrzewski Kraków University. Furthermore, he is also the head editor of scholarly journal Acta Academiae Modrevianae and the member of Publishing Board for Problemy Wspótczesnego Zarzadzania (Issues of Modern Management) 
Address:

ul. Mrówczana 1

30-231 Kraków

tel. (012) 425-28-90
Jagiellonian University

ul. Prof. St. Łojasiewicza 4

31-348 Kraków

tel. (012) 664-55-91

e-mail:wiktor.adamus@uj.edu.pl 